\title{
НОВИЙ ПОГЛЯД НА РОЗВИТОК ІНФОРМАЦІЙНОЇ СФЕРИ УКРАЇНИ
}

Концептуальні засади забезпечення сталого розвитку інформаційної сфери України : моногр. [Текст] / [Я. В. Котляревський, О. В. Мельников, А. М. Штангрет, Е. П. Семенюк, В.І.Воробйов] ; ПрАТ «Укр. наук.-дослід. ін-т спец. видів друку» ; [рец. : І. Ю. Єгоров, Т. Т. Ковальчук, М. М. Назарук]. - К. : Центр учбової літератури, 2016. - 148 c. - ISBN 978-611-01-0841-6.

Інформація і знання в умовах формування інноваційних процесів стають основою нинішнього соціально-економічного розвитку. У сучасній економічній науці багато уваги приділяється цій проблемі - розробляються і апробуються нові теорії, формуються нові підходи, створюються нові концепції та моделі постіндустріального розвитку суспільства. В основі цих розробок лежить інформаційно-знаннєвий підхід. Інформація і знання $€$ взаємопов'язаними категоріями, оскільки знання можуть бути джерелом інформації, а сукупність інформації, її аналіз, синтез народжують нові знання. У цій системі протиріч обов'язковою $\epsilon$ участь людини-творця нових знань і головного чинника економічного зростання.

Вагомим внеском у забезпечення сталого розвитку національної економіки та її складової інформаційної сфери є монографія «Концептуальні засади сталого розвитку інформаційної сфери України», що побачила світ минулого року в київському видавництві «Центр учбової літератури». Автори книги фахівці з інформаційної діяльності та наукознавства: Ярослав Вікторович Котляревський - заступник директора з науково-організаційної роботи Науково-дослідного фінансового інституту ДННУ «Академія фінансового управління» та професор кафедри організації видавничої справи, поліграфії і книгорозповсюдження Видавничо-поліграфічного інституту КПІ ім. Ігоря Сікорського, д-р екон. наук, проф.; Олександр Валерійович Мельников - докторант Науково-дослідного фінансового інституту ДННУ «Академія фінансового управління», член науково-технічної ради при Державному комітеті телебачення і радіомовлення України, канд. техн. наук; Андрій Михайлович Штангрет - завідувач кафедри фінансово-економічної безпеки та бухгалтерського обліку Української академії друкарства, д-р екон. наук, проф. Едуард Павлович Семенюк завідувач кафедри філософії та психології Національного лісотехнічного університету України, д-р філософ. наук, проф.; Віталій Іванович Воробйов - заступник директора $з$ науково-орга- 
нізаційної роботи ДНУ «Велика українська енциклопедія», канд. екон. наук (інформація про авто-рів на момент виходу книги у світ).

Незважаючи на високі темпи зростання об'єму інформаційних ресурсів у світі, вітчизняна інформаційна діяльність не стала основною передумовою забезпечення сталого розвитку економіки країни. Та й сама інформаційна діяльність не демонструє стабільного розвитку, оскільки залежить від багатьох факторів внутрішнього і зовнішнього характеру, які не сприяють її розвитку. Про проблеми в інформаційній діяльності країни свідчить поява нових понять: інформаційна політика, інформаційний суверенітет, інформаційна війна, інформаційна безпека, інформаційні війська тощо. Вони характеризують безпекову, ідеологічну складову, зміст, оперативність, дієвість суб'єктів інформаційної діяльності. Автори рецензованої монографії послуговуються більш широким поняттям інформаційна сфера. Отже, маємо справу з дещо іншим - ширшим і глибшим поглядом на інформаційну діяльність, яка окрім видавничополіграфічної діяльності включає кінематограф, радіомовлення та телебачення, Інтернет. Результатом їх функціонування $€$ інформаційна продукція та інформаційні послуги (С. 34-50).

Автори характеризують інформаційну сферу як економічну систему і пропонують власну модель, що описує іï функціонування, ґрунтуючись на роботах професорів $P$. $M$. Машталіра та О. А. Баранова. Підсистемами запропонованої моделі виступають: авторське середовище, інформаційно-аналітична діяльність, інформаційні послуги, поширення (передавання) інформаційної продукції та її споживання (С. 51-62).

Заслуговує уваги матеріал присвячений стримулюючим і стримуючим факторам розвитку вітчизняної інформаційної сфери (С. 70-81), які на нашу думку у подальших дослідженнях доцільно доповнити такими чинниками, як обмеженість природних ресурсів, залежність від технічних засобів і витратних матеріалів.

Монографія містить передмову, три розділи, висновки, літературні джерела і додатки. у першому розділі висвітлені питання еволюції теоретико-методологічних поглядів на сталий розвиток. Другий розділ присвячений сутності та ключовим параметрам формування інформаційної сфери в Україні. Основні положення концепції забезпечення сталого розвитку інформаційної сфери в країні сформовані у третьому розділі. Необхідно відзначити, що автори опрацювали і систематизували значну кількість вітчизняних й іноземних наукових джерел (понад двісті), присвячених даній проблемі. Цінними у рецензованій 
монографії є додатки, які містять унікальну статистичну інформацію про розвиток складових інформаційної сфери України за 2002-2015 рр.

Хочу висловити деякі зауваження, що стосуються структури монографії та стилю викладення матеріалу. Вважаю, що при створенні книги доцільним було перенести п. 2.1 (Формування та розвиток поглядів на сучасний етап розвитку суспільства) у розділ 1 (Еволюція теоретико-методологічних поглядів на концепцію сталого розвитку), а п. 2.2 (Інформаційна продукція) поставити після п. 2.5 .2 (Інформаційно-аналітична діяльність). У монографії відсутнє обговорення (дискусія), а містяться узагальнення авторів. Це може свідчити про «постановочний» характер дослідження та потребу у його продовженні.

Кожне справжнє наукове дослідження містить новий погляд на досліджувану проблему, елементи новизни, характери- зується певною практичною цінністю. Це дослідження не є виключенням 3 цього правила: автори рецензованої книги вперше охарактеризували інформаційну сферу як сукупність взаємопов'язаних процесів зі створення, розмноження (тиражування), поширення (продажу) і споживання інформаційних ресурсів (С. 34-64); зробили спробу сформувати концепцію забезпечення її сталого розвитку (С. 64-90); визначити систему індикаторів функціонування інформаційної сфери (С. 87-90).

Не викликає сумнівів, що монографія «Концептуальні засади сталого розвитку інформаційної сфери України» $€$ корисною і потрібною науковцям і фахівцям інформаційної сфери, студентам ВНЗ і всім, хто цікавиться інформаційною та економічною політикою держави. Хочеться побажати авторам подальших успіхів у наукових пошуках та реалізації поставлених цілей і завдань!

л. А. Швайка, к.е.н., доцент, Українська академія друкарства 